PAEDAGOGIA ChristianA

$1 / 25$ (2010) - ISSN 1505-6872

Bogusław Śliwerski*

Łódź

\title{
Czy możliwy jest w szkole dialog?
}

W jednym z numerów wydawanego przez Radę Edukacji Narodowej Zespół Oświaty Niezależnej „wielomiesięczniku” Edukacja i Dialog Julian Radziewicz przypomniał podstawowe idee samorządności, które w okresie PRL były łamane tak zwaną samorządnością ${ }^{1}$. Mieliśmy bowiem do czynienia z sytuacją występowania „samorządności przeciw samorządności”, albo pseudosamorządności czy samorządności pozorującej samorządność. Rozparcelowanie samorządności na poszczególne podmioty, czyli osobno dla uczniów, osobno dla nauczycieli i rodziców, było wyrazem tego, ,[...] jakby ci uczniowie, nauczyciele, te szkoły istniały na osobnych wyspach, obleganych przez obojętne i nic nikomu nie szkodzące wody. Rzadko wiąże się te «pożądane symptomy» samorządności z prawem do autonomii w skali szerszej, całego systemu oświatowego, a ten - w kontekście systemu społeczno-politycznego" ". Istota zła w oświacie tkwiła - zdaniem J. Radziewicza-głównie w tym,

że między szlachetnie brzmiącymi założeniami i zaklęciami (Samorządność! Podmiotowość! Partnerstwo! Postęp Pedagogiczny!) a rzeczywistością istnieje rozbieżność nie mniejsza niż dystans między małym fiatem a seryjnym volkswagenem. Rozbieżność ta jest widoczna w sferze najczulszej: sterowaniu niesamorząadnym systemem oświatowym, tak by pozostawał on nadal niesa-

* Prof. dr hab. Bogusław Śliwerski - pedagog, prof. zwyczajny Dolnośląskiej Szkoły Wyższej we Wrocławiu; wiceprzewodniczący Komitetu Nauk Pedagogicznych PAN, wiceprzewodniczący Polskiego Towarzystwa Pedagogicznego.

1 J. Radziewicz, Samorzadność przeciw samorzqdności, „Edukacja i Dialog” 7 (1988).

2 Tamże, s. 6. 
morządny, przy obwieszeniu go ze wszystkich stron transparentami z wyżej wymienionymi zaklęciami ${ }^{3}$.

Brak prawdziwej samorządności w szkole i w systemie oświaty czynił je bardziej środowiskami instytucjonalnymi niż wychowawczymi, które były oddalone od spraw ludzkich. To był też powód, dla którego uczniowie emigrowali wewnętrznie, uciekali w alkohol, narkotyki, a przede wszystkim wagarowali, uciekali ze szkoły jak z więzienia. ,Dlaczego uciekają? [...] bo nie czują się tu u siebie: wszystko tu jest dla nich wrogie, albo choćby tylko niechętne czy obojętne. To instytucja. Uciekają do ludzi, jacy by nie byli ci ludzie"4.

W czasie prowadzonych przez ,Solidarność” rozmów ze stroną rządową w dn. 29 kwietnia 1981 r. na temat realizacji Porozumień Gdańskich, w tym m.in. ówczesnych postulatów w zakresie uspołecznienia i autonomii szkoły jako środowiska wychowawczego, chodziło - jak pisze Wit Mader:

o los dzieci i o samorządny, autonomiczny kształt polskiej oświaty; o nową, nie podporządkowaną celom ideologicznym koncepcję wychowania dzieci i młodzieży, której ideę można sprowadzić do wielokrotnie wyrażanej opinii, że «szkoła ma służyć dziecku». [...] Aby szkoła mogła rzeczywiście służyć dobru dziecka, musi być uwolniona od konieczności realizacji doraźnych dyrektyw władz oświatowych, dyrektyw stojących w sprzeczności z jej celem podstawowym. Będzie to możliwe jedynie wówczas, gdy szkoła stanie się placówką autonomiczną i niezależną od aktualnej polityki administracji oświatowej, gdy nauczyciele i wychowawcy nie będą oceniani wedle stopnia swego konformizmu wobec administracji, lecz według rzeczywistego działania na rzecz fizycznego, umysłowego, emocjonalnego i moralnego rozwoju ich uczniów i wychowanków i gdy ponosić będą pełną osobistą odpowiedzialność wobec uczniów i ich rodziców za jakość swojej pracy $^{5}$.

Proponowano wówczas w ramach zwiększenia autonomii szkół wybieranie ich dyrektora przez radę pedagogiczną i nadanie tej radzie prawa ustalania wychowawczego stylu pracy szkoły, podejmowania eksperymentów pedagogicznych oraz pozostawienia jej swobody dysponowania budżetem. Żądano prawa tworzenia szkół i „klas autorskich”, a także zakładania pla-

${ }^{3}$ Tamże.

${ }^{4}$ Tamże, s. 7a.

5 W. Mader, Walka „Solidarności” o społeczny ksztalt oświaty w Polsce, Londyn 1988, s. 89-90. 
cówek przez stowarzyszenia i instytucje społeczne, naukowe i wyznaniowe. Walny Zjazd „Solidarności” we wrześniu 1981 r. podjął zasadnicze uchwały także w sprawach oświatowych. Przede wszystkim dotyczyły one centralizacji władzy w wyniku likwidacji inspektoratów szkolnych, by nie dublować ich roli z rolą dyrektorów szkół, zobowiązania administracji oświatowej do pełnienia wobec placówek roli służebnej, poprzez zapewnianie uczniom i nauczycielom właściwych warunków finansowych, lokalowych, w zakresie wyposażenia i zapewnienia kadr, a także dzięki zachowaniu autonomii placówek wobec instancji wyższych. Szkoły powinny „działać na zasadzie samorządności wewnętrznej, czyli decyzje powinni podejmować zarówno wychowawcy, jak młodzież. Funkcje kontrolne w takim układzie sprawowałaby Społeczna Rada Oświaty i wychowania, powoływana przez Sejm. W skład jej wchodziliby pedagodzy, rodzice i osoby cieszące się szczególnym autorytetem moralnym. Dyrektor szkoły powinien być wybierany przez radę pedagogiczna, podlegać jej oraz Radom Oświaty i Wychowania, natomiast zachować niezależność od administracji. Rolą Społecznej Rady byłaby kontrola nad Ministerstwem Oświaty i wspomaganie jego przedsięwzięć"6.

Postulowane przez Związek uspołecznienie oświaty miałoby nastapić przez zapewnienie jej tak rozumianej samorządności. „Społeczeństwo musi

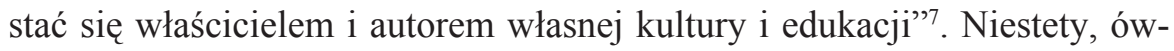
czesne ministerstwo oświaty nie zamierzało przejmować się tymi postulatami, tylko tak jak władze polityczne grało z ruchem związkowym na zwłokę. W listopadzie rozpoczął się strajk lubelski, gdyż nie godzono się na łamanie przez władze ustaleń dotyczących m.in. porozumień w sprawie konsultowania społecznego kandydatur osób na stanowisko kuratora oświaty. Jak stwierdzono w komunikacie z dn. 22 listopada 1981 r.: „Nauczyciele walczą o to, by: społeczeństwo nadzorowało oświatę; w szkołach nauczano tylko prawdy; dzieci miały znośne warunki życia w szkołach i internatach; oświatą kierowali ludzie odpowiedzialni. ,Solidarność” nauczycielska [...] od 6 tygodni żąda cofnięcia nominacji na kuratora p. Jagowdzikowi, wyboru kuratora z konkursu, realizacji postulatów"8.

Szkoła lat transformacji miała się zatem przekształcać ze szkoły jako agendy niedemokratycznego państwa w szkołę bezradnie i nieskutecznie usiłującą się wyzwolić spod wpływów nowych form dominacji politycznej i ideologicznej ku szkole humanistycznej, dialogowej, demokratycznej. Edukacja szkolna zgodnie ze swoimi założeniami powinna służyć maksymalizowaniu potencjału rozwojowego wszystkich uczniów, sprzyjać osiąganiu

\footnotetext{
${ }^{6}$ Tamże, s. $120-121$.

7 Tamże, s. 121.

8 Tamże, s. 138.
} 
przez nich sukcesów na miarę ich aspiracji i możliwości, powiększać kulturowy kapitał, by procentował w ich dalszym życiu. Szkoła (starogreckie scholé) powinna być miejscem spokoju, wolności, odpoczynku, tajemniczego uroku, oddania się czynnościom wzbogacającym, sprawiającym radość. Okazuje się jednak, że od jej źródłowego znaczenia instytucja ta - w sensie powszechnym - jest wciąż jeszcze bardzo oddalona. Niektórzy nawet twierdzą, że szkoła z założenia nie jest instytucją powołaną do dialogowania z dziećmi i do przestrzegania w niej zasad podmiotowości, solidarności, demokracji, tolerancji, sprawiedliwości czy wolności.

W sposób niezgodny z ideą demokracji upowszechniło się jednak w szkolnictwie przekonanie, że wzajemne stosunki władz oświatowych z dyrektorami szkół, dyrektorów z nauczycielami oraz tych ostatnich z uczniami i ich rodzicami muszą być oparte na autorytecie formalnym (władzy, instytucji) wyżej usytuowanej w społecznej hierarchii osoby, przy czym przez autorytet rozumie się tu określony stopień posłuszeństwa czy podporządkowania. Autorytarne społeczeństwo bardziej jednak sprzyja kształceniu autorytarnych osobowości. Przed laty krytykował taki stan rzeczy przedstawiciel nurtu Nowego Wychowania - Janusz Korczak, pisząc: „Nie możemy zmienić naszego życia dorosłych, bośmy sami wychowani w niewoli, nie możemy dać dziecku swobody, dopóki samiśmy w kajdanach"".

Współczesne szkoły nadal są organizowane i prowadzone na wzór biurokratycznych instytucji państwowych końca XIX w., by realizować w nich cele zgodnie z zasadą administracyjnej racjonalności, a więc przy stosowaniu tych samych środków, w tym samym czasie i względnie tych samych warunkach. Chodzi o to, by do maksimum wykluczyć z ich funkcjonowania przypadek (los), co - jak się wydaje - jest możliwe tylko wówczas, kiedy postępowanie jednostek $\mathrm{w}$ instytucji nie będzie warunkowane ich indywidualnymi potrzebami i uniezależni się od ich subiektywnych doznań. Tak rozumianej racjonalności poddano nie tylko czas trwania szkoły, metody nauczania, jej wyposażenie w pomoce dydaktyczne, ale i ocenianie zachowania uczniów czy postaw nauczycieli. Okres PRL-owskiego państwa totalitarnego sprzyjał nadużywaniu władzy na każdym szczeblu zarządzania szkołami, w tym niestety także toksycznym postawom cześci nauczycieli wobec uczniów, a nawet ich rodziców.

Humanistycznego typu orientacja szkół, choć w rozwinięciu przepisów ustawy jest dość licznie reprezentowana, to jednak w rzeczywistości edukacyjnej jest zasadniczo marginalizowana. Szkoła przekształcając się z instytucji państwowej w publiczną, a więc tak naprawdę z instytucji swoistego rodzaju „terroru” politycznego i administracyjnego, który miał miejsce w tym

\footnotetext{
9 J. Korczak, Pisma wybrane, t. 1, Warszawa 1984, s. 187.
} 
kraju przez wiele lat, w placówkę publiczna, uspołecznioną musiała od początku lat 90. uczyć się rozumienia samej siebie, uczyć się swojej wolności. Wbrew zapowiedziom kolejnych rządów o rekonstruowaniu tej instytucji w kierunku jej uspołecznienia (społeczeństwo obywatelskie, samorządność szkolna), zwiększenia poziomu i zakresu decentralizacji i decentracji władztwa pedagogicznego, nadal odtwarzała właściwą dla systemów hierarchicznych strukturę nadrzędności i podporządkowania.

Jak szkoła ma być wspólnotą wychowująca, skoro wciąż obowiązuje w niej posłuszeństwo rodziców wobec nauczycieli, „małych” uczniów wobec „wielkich” pedagogów, słabszych wobec silniejszych, podwładnych wobec zwierzchników? Po kilkunastu latach budowania zrębów państwa prawa na zasadach ustroju demokratycznego prawdopodobnie już tylko oświata opiera się jego procesom. Wydaje się to wręcz nieprawdopodobne, że instytucje powszechnego kształcenia, które powinny być „kołem napędowym” przemian społeczno-ustrojowych i kulturowych, stają się inhibitorami reform, czyli czynnikiem opóźniającym zaistnienie zmian. Pomimo przesłanek prawnych, jakie udało się wprowadzić do oświatowego ustawodawstwa w III RP ogromny wysiłek i podziemna walka czołowych przedstawicieli świata kultury, nauki i edukacji w okresie PRL nie zostały właściwie skonsumowane.

Akceptowana i wdrażana przez niektórych polityków zasada zwiększania poziomu autokratyzmu władzy, zastraszania nauczycieli, dyscyplinowania uczniów i wycofywania się z reform o charakterze liberalnym trafia w Polsce na podatny grunt. Nie jest bowiem prawdą, że w ciagu kilkunastu lat transformacji ustrojowej doszło w polskiej oświacie do całkowitego rozprzężenia systemu wartości, anarchizacji zachowań uczniów czy zaniedbań dydaktyczno-wychowawczych. Nie przypominam sobie, by którakolwiek z ekip rządzących tak właśnie formułowała naczelne cele swojej polityki oświatowej. Incydentalne wydarzenia, choć miały miejsce w różnych szkołach, potwierdzają jedynie, iż polska szkoła jeszcze nie wyszła z pozostałości po systemie totalitarnym okresu PRL, a już powraca się w rozwiązaniach oświatowych do sprawdzonych w nim rozwiązań organizacyjnych, choć osadzonych w odmiennym systemie wartości.

Nie powstały w Polsce rady szkolne w stopniu i natężeniu, który pozwalałby na powołanie do życia wojewódzkich rad oświatowych czy krajowej rady oświaty. Władze MEN jakby tylko na to czekały. Skorzystały z bierności obywatelskiej i z braku społecznego zaangażowania uczniów i ich rodziców, wycofując w 2002 r. możliwość oddolnego budowania struktur uspołecznienia oświaty ${ }^{10}$. Jak słusznie podsumował ten okres w jednym ze swoich artykułów Zbigniew Kwieciński:

${ }^{10}$ Szerzej w: B. Śliwerski, Rada szkoły. Rada oświatowa, Kraków 2002; tenże, Problemy współczesnej edukacji. Dekonstrukcja polityki oświatowej III RP, Warszawa 2009. 
W latach 1981-2008 oświata w Polsce jako system się rozsypała, w tym, kilka jego podstawowych części składowych (podsystemów), takich jak: opieka przedszkolna, szkolnictwo zawodowe, kształcenie i dokształcanie nauczycieli, kształcenie ustawiczne. Była niszczona wspólnymi siłami chaotycznej adaptacji do oczekiwań społecznych, gasnących wydatków państwa, wyłaniającego się rynku i przypadkowym naśladownictwem różnych wzorów zachodnich i z własnej przeszłości, szybkiej wymiany coraz to nowych centralnych decydentów, którzy stale byli podobni do siebie pod względem niekompetencji i braku odpowiedzialności ${ }^{11}$.

W świetle badań krytycznych codzienne życie w szkołach postrzegane było przez uczniów w kategoriach wciąż istniejącej w niej przemocy. Badacze zwrócili bowiem uwagę na nie tylko zabronioną w tej instytucji, ale wciąż obecną przemoc fizyczną nauczycieli wobec uczniów, ale także na przemoc psychiczną (tzw. przemoc w „,białych rękawiczkach”), jaką stosują niektórzy instytucjonalni wychowawcy wobec swoich podopiecznych w postaci: obelg, pomówień, szantażu, gróźb, etykietowania, bagatelizowania, publicznego obnażania, agresji słownej itp. W świetle wycinkowych diagnoz już na początku lat 90. okazywało się, że wśród najczęściej stosowanych przez nauczycieli praktyk poniżających godność ucznia występowały takie ich zachowania, jak: mściwość (83\% wskazań), poniżanie uczniów (82\%), złośliwość (79\%), wyśmiewanie uczniów (71\%) oraz stawianie niesprawiedliwych ocen $(67 \%)^{12}$. Mieliśmy zatem do czynienia z zamierzoną lub niezamierzoną (afektywną) agresją czy wrogością nauczycieli w stosunku do uczniów, prowadzącą do ranienia wychowanków.

Przejawy tak rozumianych nieetycznych postaw nauczycieli wobec uczniów wykazały także badania Wojciecha Muzyki i Jadwigi Bińczyckiej, których interesował typ mentalności polskiego nauczyciela w kontekście ofert edukacyjnych polskiej szkoły. Wynika z nich, że to nauczyciele byli niedostosowani do głęboko i szybko zmieniającej się rzeczywistości szkolnej i że instytucja ta okazała się przestarzała dydaktycznie oraz zdehumanizowana psychospołecznie. Wśród stosowanych przez nauczycieli form przemocy znalazły się m.in.: intrygi, kłamstwa, szantaż, manipulowanie, tworzenie sytuacji, przez co - jak oceniali to uczniowie - (pseudo)pedagodzy stawali się śmieszni i niegodni uwagi. Nauczyciele stali na straży dyscypliny jako bezwzględnej konieczności przestrzegania przez uczniów reguł szkolnych

${ }^{11}$ Z. Kwieciński, O reformie oświaty: co wyrównywać, co różnicować, czego najbardziej potrzeba. Głos w dyskusji, w: H. Moroz (red.), Problemy doskonalenia systemu edukacyjnego $w$ Polsce, Kraków 2008, s. 13.

${ }^{12}$ E. Czyż (red.), Dziecko i jego prawa, Warszawa 1992, s. 74. 
(70,5\%), oczekiwali bezwzględnego podporządkowania się $(49,2 \%)$ i szanowania ich $(21,3 \%)$, nie wiążąc tego zjawiska $\mathrm{z}$ własną sprawiedliwością, zaufaniem czy szacunkiem wobec uczniów ${ }^{13}$.

Uczniowie zapytani przez J. Bińczycką o treść snów o szkole ujawnili w postaci marzeń o zemście swoją podświadomą wobec niektórych nauczycieli agresję i niechęć typu: „połamałbym mu kości i dał psom, utworzyłbym obóz i tam zamknął wszystkich nauczycieli, nadałbym na niego mafię pruszkowską; przed domem rozlałbym mu walerianę i potem patrzył jak tam zbiegają się wszystkie koty z okolicy"14. Szkoła zatem okazała się przestrzenią instytucjonalnej przemocy części nauczycieli wobec uczniów, a zarazem odsłoniła swoją bezradność, by ją wyeliminować z własnego pola działań pedagogicznych. Badacze zaczęli zwracać zatem uwagę na istniejące w szkołach zagrożenie godności dzieci w sytuacjach dydaktycznych i pozalekcyjnych oraz na konieczność jej obrony w imię ustawowych dla polskiej oświaty wartości humanistycznych, w tym chrześcijańskich. Odstąpienie od powszechnej kontroli i samoregulacji w tej sferze społecznego życia zawsze prowadzi do przyzwolenia i utrwalania się zła w stosunkach międzyludzkich, niszczy wartość pedagogicznych oddziaływań i uniemożliwia wyjście współczesnego wychowania z permanentnego kryzysu.

Prowadzone pod moim kierunkiem w 2003 r. badania nad postrzeganiem szkoły przez uczniów jednego z zespołów szkół ponadgimnazjalnych w woj. łódzkim wykazały, że tylko 32,7\% uczniów kierowało się w wyborze tej szkoły takimi pobudkami pozytywnymi, jak: zainteresowania, chęć realizowania planów na przyszłość, uzyskania wykształcenia oraz „inność” tejże szkoły w porównaniu z tradycyjnym liceum ogólnokształcącym. Aż 26,6\% uczniów wiązało fakt uczęszczania do szkoły z przymusem, z brakiem innego wyjścia czy wyboru. Większość uczniów przeżywała negatywne uczucia na myśl o pójściu do szkoły. Uczniowie odczuwali w związku ze szkołą najczęściej: negatywne napięcie (50\%), niechęć (34,7\%), myśl o ucieczce $(30,6 \%)$ i nudę $(29,6 \%)$ oraz stan niezadowolenia $(23,5 \%)$. W przypadku odczuć pozytywnych na pierwszym miejscu wskazywali na radość na myśl o spotkaniu z rówieśnikami $(78,6 \%)$. Idealny uczeń to dla nich przede wszystkim osoba koleżeńska (25\%), pracowita (17\%), pilna (15\%), dobrze się ucząca (13\%), systematyczna (12\%), mądra i pomocna (po 11,2\%).

Idealny wychowawca - jak napisał jeden z uczniów - to musi być człowiek, który jest prawdziwym nauczycielem. Pisząc prawdziwy mam na myśli na-

${ }^{13}$ M. Dudzikowa (red.), Nauczyciel-uczeń. Między przemocq a dialogiem: obszary napięc i typy interakcji, Materiały z Sekcji XV Polskiego Towarzystwa Pedagogicznego, II Ogólnopolski Zjazd Pedagogiczny, Kraków 1996.

${ }^{14}$ Tamże, s. 47. 
uczyciela z powołania. Sam zamierzam zostać nauczycielem i często się nad tym zastanawiam. Bardzo istotne jest, aby nauczyciel, wychowawca nie poniżał swoich podopiecznych, miał z nimi więź, która z biegiem czasu powinna przekształcić się w przyjaźń. To musi być człowiek, do którego zawsze można się zwrócić o pomoc, który wysłucha i spojrzy na twój problem obiektywnie! ${ }^{15}$

Niepokojące jest to, że ponad połowa badanych $(56,1 \%)$ negatywnie ustosunkowała się do pytania: „Czy nauczyciele interesują się Tobą i Twoimi problemami?". Sami uczniowie nie postrzegali też siebie jako mających wpływ na życie klasy czy szkoły. Prawie 70\% badanych twierdziło, że ma niewielki wpływ na to, co dzieje się w klasie (48\%) lub nie ma żadnego wpływu (21,4\%). Zaskakujące było to, że zdaniem 22,4\% uczniów nauczyciele stosują kary fizyczne, wśród których przeważają uderzenia $(8,2 \%)$, kara w postaci sprzątania sanitariatów $(5,1 \%)$ czy kopnięcia $(3,1 \%)$. Dla ogromnej większości szkoła powinna położyć większy nacisk przede wszystkim na budowanie w uczniach wiary w siebie i w swoje możliwości (90,8\%), następnie przygotowywanie do skutecznego posługiwania się językiem obcym $(84,7 \%)$ oraz stwarzanie równych szans do startu życiowego młodzieży $z$ różnych środowisk $(83,7 \%)$. Istotnym jest także w opinii uczniów przygotowanie ich do znalezienia pracy $(80,6 \%)$, rozwijanie poczucia solidarności społecznej, chęci pomagania sobie nawzajem (78,6\%), kształcenie zainteresowań $(78,6 \%)$ oraz umiejętności społecznych (77,6\%). Dopiero na ostatnich pozycjach znalazło się kształtowanie charakteru i kultury osobistej (74,5\%), rozwijanie samodzielności, przedsiębiorczości $(74,5 \%)$ oraz zapewnienie wysokiego poziomu wiedzy ogólnej $(53,1 \%)$.

„Konflikty między rodziną i szkołą obarczają dziecko. Rodzice solidaryzują się z nie zawsze sprawiedliwym oskarżeniem dziecka przez szkołę, broniąc się przed narzucaną przez szkołę opieką" "I6 Z uczniem solidaryzuje się jedynie jego najbliższy przyjaciel lub kolega podobnej niedoli, znacznie rzadziej własny rodzic (pouczany i straszony sankcjami wobec jego dziecka w czasie wywiadówek przez wychowawcę klasy), a już najmniej nauczyciel. Solidarność wymaga bezinteresownej więzi i gotowości do wyrzeczeń w noszeniu ciężaru drugiego człowieka. Ilu jednak nauczycieli przejmuje się trudami dziecięcej edukacji? Ilu spośród nich łączy się w walce o słuszną sprawę nawet wówczas, gdyby musieli wystąpić przeciwko swojemu pracodawcy (dyrektorowi szkoły)?

${ }^{15}$ M. Kulig, Szkoła w świadomości młodzieży, niepublikowana praca magisterska pod kierunkiem B. Śliwerskiego, Łódź 2003.

${ }^{16}$ J. Korczak, dz. cyt., s. 76. 
Współczesna polska szkoła jest społecznością pozornie solidarna, gdyż częściej jednoczy ją strach i przymus, aniżeli zjednoczenie sumień, autentyzm działań, dobra wola, profesjonalizm i wspólnota ludzkich serc ${ }^{17}$. Nauczyciele i dyrektorzy szkół nie mogą pogodzić się z przenikaniem do szkół idei demokracji uważając, że nie są one do tego powołane. W efekcie tego rządzeni nie są zarazem rządzącymi. Nadal o sprawach uczniów stanowi się bez ich aktywnego i rzeczywistego udziału (o nich bez nich), lekceważąc także najważniejszych rzeczników ich interesów i potrzeb, jakimi są ich rodzice. Ci bowiem też mają niewiele w szkole do powiedzenia poza przyzwoleniem władzy na materialne ratowanie instytucjonalnego ubóstwa i nędzy infrastrukturalnej. Nauczyciele nie są zainteresowani samorządnością własnej grupy zawodowej, naiwnie licząc na załatwienie ich spraw przez związki zawodowe ${ }^{18}$. W szkołach obowiązuje idea demokracji proletariackiej, czyli łączenia w sobie przez poszczególne podmioty (przez dyrektorów wobec nauczycieli, a nauczycieli wobec uczniów i ich rodziców) wyłączności na prawdę z siłą instrumentów przemocy (negatywna selekcja uczniów, restrykcje wobec niepokornych nauczycieli czy izolacjonizm w stosunku do rodziców zbytnio interesujących się rzeczywistymi przyczynami zła w szkole). Niektórzy dyrektorzy, akceptując ideę demokracji, ubolewają, że muszą wdrażać jej mechanizmy w życie, toteż bezkarnie uczestniczą w biernym oporze wobec niej oraz stosują jawny lub ukryty sabotaż $\dot{1}^{19}$.

Nie pozwalamy się dzieciom zorganizować; lekceważąc, nie ufając, niechętni, nie dbamy; bez rzeczoznawców udziału nie podołamy; a rzeczoznawcą jest dziecko. [...] Nie pozwalamy dzieciom krytykować ani się sami kontrolujemy. Rozgrzeszeni zrzekliśmy się walki z sobą, obarczając ciężarem jej dzieci. [...] Dziecko nie jest głupie; głupców wśród nich nie więcej niż wśród dorosłych ${ }^{20}$.

Potwierdzą tę korczakowską diagnozę J. Pielachowski - przekonując nauczycieli, że ,[...] opinie uczniów mogą być dojrzałe, a równie dobrze niedojrzałe, tendencyjne czy powierzchowne. W znowelizowanej ustawie o systemie oświaty (lipiec 1995) w art. 51. ust. 5a zapisano: W regulaminie (rady szkoły) mogą być określone rodzaje spraw, w których rozpatrywaniu nie biorą udziału przedstawiciele uczniów".

${ }^{17}$ B. Śliwerski, Wyspy oporu edukacyjnego, Kraków 1993; tenże, Edukacja autorska, Kraków 1996.

${ }^{18}$ Tenże, Jak zmieniać szkołę?, Kraków 1998; tenże, Program wychowawczy szkoły, Warszawa 2002.

${ }^{19}$ Tenże, Klinika szkolnej demokracji, Kraków 1996.

${ }^{20}$ J. Korczak, dz. cyt., s. 74-80. 
Uczniowski przywilej do samorządnego zrzeszania się w szkole potraktowany jest $\mathrm{w}$ zdecydowanej większości tych instytucji nadal jako zagrożenie dla nauczycieli, którzy odczuwają nieodpartą potrzebę ingerowania w ten proces, „ręcznego" nim sterowania, by samorząd uczniowski mimo wszystko pozostał „przedłużonym ramieniem” władzy pedagogicznej. „Uczymy własnym przykładem lekceważenia [tego], co słabsze. Zła szkoła, ponura przepowiednia" 21 . Oto kilka typowych zapisów w ordynacji wyborczej do rad samorządów różnych szkół w środowisku wielkomiejskim, a więc wydawałoby się z oświeconymi nauczycielami:

- „Propozycje kandydatów na funkcję przewodniczącego samorządu uczniowskiego zgłasza zarząd poszczególnych klas do opiekuna Samorządu Szkolnego po uprzednim porozumieniu się z wychowawcą i uczniami danej klasy";

- „Datę wyborów na przewodniczącego Rady Samorządu ustala Rada Samorządu, a zatwierdza Rada Pedagogiczna";

- „Obecność członka Rady, którego dotyczy głosowanie, nie jest konieczna".

Jak szkoła ma być instytucją czy wspólnotą wychowująca, skoro wciąż obowiązuje w niej posłuszeństwo małych uczniów wobec wielkich pedagogów, słabszych wobec silniejszych, podwładnych wobec zwierzchników? Zdaniem Janusza Korczaka wychowawca

skwapliwie przyswaja dorosły przywilej: nie siebie, a dzieci pilnować, nie swoje, a dzieci registrować winy. [...] Ćwiczymy uwagę swą i wynalazczość w podpatrywaniu zła, doszukiwaniu się, węszeniu i tropieniu, przyłapywaniu na gorącym uczynku, w złych przywidywaniach i krzywdzących podejrzeniach. (Czy pilnujemy starców, by nie grali w futbol?[...]). [...] Chcemy opieszale, żeby żadne i nigdy, by z dziesięciu tysięcy sekund szkolnej godziny (oblicz) nie było żadnej trudniejszej. [...] Żądamy uniformu cnót i momentów, nadto - według naszych upodobań i wzorów ${ }^{22}$.

„[...] Urządziliśmy się tak, by nam dzieci najmniej przeszkadzały, najmniej domyślały się, czym istotnie jesteśmy i co istotnie robimy"23.

Znowelizowana w sierpniu 1996 r. Ustawa Karta Nauczyciela w regulacji dotyczącej oceny pracy nauczyciela (art. 6a, ust. 5) ustalała, że oceny pracy nauczyciela dokonuje dyrektor szkoły po zasięgnięciu opinii samorządu uczniowskiego. Co z tego, skoro w materiałach szkoleniowych dla dyrektorów pociesza się ich następującą interpretacją:

21 Tamże, s. 62.

22 Tamże, s. 80-82.

${ }^{23}$ Tamże, s. 150. 
Z całego, cytowanego wyżej zapisu wynika jedynie, że samorząd uczniów uzyskał kompetencję ustawową do opiniowania pracy nauczyciela $\mathrm{w}$ procesie dokonywania oceny tej pracy przez dyrektora. Jest to uprawnienie samorządu, które może się zrealizować dopiero po wystąpieniu dyrektora o taką opinię. (Wszelkie więc ocenianie nauczycieli «na zapas», o czym tu i ówdzie się słyszy, jest nadinterpretacją ustawy, jeśli nie bezprawiem). Co ze stanu prawnego rzeczywiście wynika? Następujące implikacje:

- Opinia samorządu uczniowskiego w procesie dokonywania oceny pracy nauczyciela może powstać dopiero po zwróceniu się o nią przez dyrektora szkoły. $[\ldots]$

- Z treści i formy zapisu nie wynika, aby opinia samorządu uczniowskiego miała moc wiążącą dyrektora. Gdyby taka moc leżała w intencji ustawodawcy, zapis musiałby wyraźnie to zaakcentować lub musiałby przyjąć postać: «dyrektor uzgadnia projekt oceny z samorządem uczniowskim». Ponieważ nic takiego w ustawie nie zapisano, wyłącznie podmiot oceniający (dyrektor) decyduje o wpływie opinii samorządu na kształt oceny lub o braku takiego wpływu. I w tym tkwi mądrość ustawodawcy! Opinie uczniów mogą być dojrzałe, a równie dobrze niedojrzałe, tendencyjne czy powierzchowne ${ }^{24}$.

Nie tylko samorząd uczniowski traktowany jest w sposób quasi demokratyczny. Także rada pedagogiczna traktowana jest w Ustawie o systemie oświaty oraz w praktyce jak zniewolony przez dyrektora szkoły organ, który spełnia swoistego rodzaju funkcję wywiadówki dla nauczycieli. Jakże mówić o demokratyzacji wewnątrzszkolnego życia i o dialogu między podmiotami szkolnej edukacji, skoro przewodniczącym tej rady jest pracodawca jej wszystkich członków. Który z nich zatem ,wychyli się” z głosem krytycznym przeciwko dyrektorowi, nie lękając się zarazem możliwości utraty czy pogorszenia warunków (np. psychologicznych) pracy? Oto w jednej ze szkół podstawowych w byłym województwie bielskim dyrektorka szkoły udzieliła upomnienia ustnego wszystkim nauczycielom (w kolejności alfabetycznej) za to, że nie dochowali tajemnicy posiedzenia rady pedagogicznej, wynosząc na zewnątrz informację o nieprawidłowościach i niegospodarności dyrektorki tej placówki ${ }^{25}$. „Baczność: życie współczesne kształtuje silny brutal, homo rapax ${ }^{26}$; on dyktuje metody działania. Kłamstwem są jego ustępstwa dla słabych, fałszem cześć dla starca, równouprawnienie kobiety i życzliwość dla dziecka”27 . „Dorośli kłamią. [...] Oni nie dotrzymują słowa: obiecu-

\footnotetext{
${ }^{24}$ J. Pielachowski, „Głos Dyrektora menedżera” 14 (1997), s. 1.

${ }^{25}$ M. Kozubal, Tajemnice rady, „Głos Nauczycielski” 44 (1994).

${ }^{26}$ homo rapax - człowiek drapieżny, rabuś.

${ }^{27}$ J. Korczak, dz. cyt., s. 87-88.
} 
ja, a potem zapominają albo się wykręcają, albo niby za karę nie pozwalają: i tak by nie pozwolili przecież. Każą mówić prawdę, a jak powiedzieć, to się obrażają. Oni są fałszywi: w oczy mówią co innego, [a] za oczy co innego. Jak kogoś nie lubią, udają, że lubią"28.

To dyrektor szkoły jako przewodniczący rady pedagogicznej wnioskuje, głosuje, uchwala i podpisuje uchwały tego organu adresowane przecież w dużej mierze do samego siebie. Potem powinien je wykonać i w trakcie kolejnego posiedzenia rozliczyć siebie samego z ich wykonania. Ustawodawca staje się dla samego siebie wykonawca, ale i zarazem sędzią we własnej sprawie, gdyż może nawet podważyć prawomocność uchwał, przyjętych przez radę pedagogiczna, której przecież sam przewodniczy. Gdyby nawet przyjąć, że właściwą rolę w procesie oddolnej kontroli „nadużyć” dyrektora szkoły wobec społeczności nauczycielskiej może spełnić rada szkoły, to przecież nie może ona powstać bez rozpatrzenia wniosku w tej sprawie przez dyrektora szkoły, który może tę inicjatywę zablokować już na poziomie oddalenia stosownego wniosku przez radę pedagogiczną czy zniechęcenia do niego rady rodziców bądź samorządu uczniowskiego. Paradoksem jest przy tym to, że ten, który ma ów wniosek rozpatrzyć, sam może być też jego wnioskodawcą jako przewodniczący rady pedagogicznej. Równie ograniczonym w rzeczywistej mocy sprawczej partycypowania w procesie kształcenia i wychowania w szkołach ich dzieci czy w współzarządzaniu szkołą jest rada rodziców, której kompetencji i możliwych form w tym zakresie w ogóle nie uwzględniono w tej ustawie.

Oto przewodnicząca rady rodziców przy jednym z łódzkich liceów zgłosiła pisemny protest do dyrektorki przeciwko wprowadzonym przez nią zmianom w tekście Regulaminu Rady Rodziców, poszukujących przecież uściśleń i przesłanek dla swojej aktywności w tej instytucji. Otóż dyrektorka wykreśliła $\mathrm{z}$ tego projektu jako niepożądane m.in. następujące zapisy (wytłuszczone):

1. Podstawową funkcją RR jest reprezentowanie ogółu rodziców uczniów szkoły przy podejmowaniu działań zmierzających do doskonalenia procesu nauczania i wychowania młodzieży oraz zapewnienia każdemu uczniowi warunków niezbędnych do jego rozwoju (w oparciu o zasady solidarności, demokracji, tolerancji, sprawiedliwości i wolności).

2. Głównym celem współdziałania rodziców ze szkołą jest ujednolicenie oddziaływania na młodzież przez rodzinę i kadrę szkolną oraz podnoszenie kultury pedagogicznej i poziomu nauczania, a także współodpowiedzialne rozwiązywanie problemów wychowawczych zgodnie z potrzebami opiekuńczymi młodzieży znajdującej się w okresie dorastania fizycznego i psychicznego.

${ }^{28}$ Tamże, s. 170. 
Rozdział VIII. „Alfabet” szczegółowych zadań RR.

„b) dokonywanie wspólnie z wychowawcami klas oraz z innymi nauczycielami i dyrekcją, analizy i oceny wyników nauczania, zainteresowań i zachowań uczniów."

„h) współdziałanie na rzecz stałej poprawy warunków pracy i wypoczynku uczniów i nauczycieli."

Niewatpliwie J. Korczak był w polskiej praktyce pedagogicznej prekursorem wdrożenia idei uspołecznienia procesu kształcenia i wychowania, pisząc m.in.: ,Szkoła tworzy rytm godzin, dni i lat. Urzędnicy szkoły mają zaspokajać dzisiejsze potrzeby młodych obywateli. Dziecko jest istotą rozumną, zna dobrze potrzeby, trudności i przeszkody swego życia. Nie despotyczny nakaz, narzucone rygory i nieufna kontrola, ale taktowne porozumienie, wiara w doświadczenie, współpraca i współżycie"29. Wydawałoby się zatem, że po to właśnie sięgnięto z początku lat 90. po ideę uspołecznienia szkół, by przerwać łańcuch potajemnych sądów kapturowych nad dzieckiem.

Coraz częściej diagnozy wskazują na nieposzanowanie w szkołach zasady sprawiedliwości. Najsilniej przejawia się to $\mathrm{w}$ procesie oceniania uczniów, ale i nauczycieli czy dyrektorów szkół. Badania psychologów nad poczuciem krzywdy uczniów w szkole wykazują, że jej poczucie występuje najsilniej w relacjach nauczyciel-uczeń. Procesowi oceniania osiagnięć szkolnych zawsze towarzyszy współczynnik subiektywizmu nauczycieli, gdyż każdy z nich przywiązuje różną wagę do określonych umiejętności i wiadomości, niektórzy zaś dodatkowo kierują się przy ocenianiu sympatiami lub antypatiami, pozycją społeczną rodziców, pochodzeniem ucznia, jego płcią, aparycją itp.

Niesprawiedliwe traktowanie uczniów przez nauczycieli wynika z ich niechęci do uczniów mniej zdolnych, niepokornych, mających własne zdanie czy opinię. Niedopuszczalne jest przy tym, ich zdaniem, jakiekolwiek przyzwolenie uczniom czy ich rodzicom na ocenianie nauczycieli czy dyrekcji szkoły. Nawet znowelizowana w 1996 r. Ustawa Karta Nauczyciela w regulacji dotyczącej oceny jego pracy przez samorząd uczniowski wskazywała na pozorne uprawnienie tego organu, gdyż może się ono zrealizować dopiero wówczas, kiedy dyrektor szkoły sam wystąpi do tego samorządu o stosowną opinię. To jednak wcale nie musi mieć miejsca, a jeśli nawet zaistnieje, to i tak nie ma ona mocy wiążącej dla dyrektora.

Nie wiadomo, co sprawia, że kwestie etyczne nie są czynnikiem rozstrzygającym o prawomocności wykonywania zawodu nauczyciela. Mimo iż postępowanie nauczyciela może prowadzić do negatywnych i względnie trwałych śladów w osobowości jego wychowanków, to jednak wymyka się

29 amże, s. 76. 
ono spod możliwej kontroli czy opinii zewnętrznej (publicznej), a tym samym nie pociaga za sobą jego osobistej odpowiedzialności (w sensie prawnym), chyba że w swoim postępowaniu nauczyciel przekroczył powszechnie obowiązujące normy prawne (np. nietykalności cielesnej). Jak zatem wyegzekwować od pedagoga miłość, szacunek, takt, życzliwość, empatię, autentyczne zaangażowanie czy dobrą wolę wobec dzieci, skoro owe normy nie są objęte żadnym aktem prawnym?

Uczeń jest w porównaniu z nauczycielami nie tylko osobą o niższym poziomie rozwoju psychospołecznego, ale też, podobnie jak pacjent w relacji z lekarzem, jest w pewnym sensie osobą bezradną i zdaną na dobrą wolę i życzliwość swoich opiekunów. Będąc dzieckiem, a więc przedmiotem prawa, nie może świadczyć we własnej sprawie, dochodzić wprost swoich racji. Może liczyć jedynie na spolegliwość rodziców czy instytucjonalnych opiekunów, którzy z mocy prawa mogą reprezentować jego interesy. Czy jednak dorośli podejmują się jakiejkolwiek interwencji? To zależy od ich dobrej woli, kompetencji i odwagi cywilnej. Szkołę jako toksyczną instytucję toczy choroba moralna, zarażając jak chemiczna trucizna jednostki ludzkie czynnikami wyniszczającymi ich zdolność do akceptowania i realizowania norm społeczno-etycznych oraz do autonomicznego rozwoju. System taki nosi w sobie zarzewie moralnego zła, przy równoczesnym zakładaniu w ustawowych normach dążenia do dobra. Najwięcej jednak zła - jak twierdzi jeden ze współczesnych filozofów francuskich Andre Glucksman - „wyrządza się zawsze w imię Dobra, czyli pewnej idei człowieka" ${ }^{\text {"30 }}$.

Pytając zatem o toksyczność społeczna, poszukujemy zarazem szeroko rozumianej przemocy, pogardy dla jednostki ludzkiej oraz naruszania przez pedagogów humanistycznych racji i wartości. System toksyczny zatem to system krzywdzący jednostki ludzkie (szczególnie dzieci, osoby starsze, kalekie czy chore) w wyniku przekroczenia obowiązujących praw i lekceważenia uniwersalnych wartości, a przez to naruszający godność ludzką. To taki system, który cechuje swoistego rodzaju choroba, patologia z tej racji, iż upowszechnia on i wdraża do negatywnych postaw czy zachowań, doprowadzając wśród swoich uczestników do co najmniej jednego z rodzajów szkód: moralnych, społecznych, fizycznych lub psychicznych. Ze względu na swoje właściwości system ów wywiera szkodliwy wpływ na osoby, powodując niekorzystne skutki dla ich rozwoju lub stanu pożądanego współdziałania.

Skutki działań niszczycielskich w psychice młodego człowieka moga być silne, rozległe i trudne do zidentyfikowania w kategoriach bezpośredniego i moralnego sprawstwa. Pod tym względem zawód nauczycielski, po-

\footnotetext{
${ }^{30}$ Porozumienie przeciwko diablu, Wywiad G. Dobieckiego z A. Glucksmanem, „Gazeta Wyborcza“" z dn. 31.07.1993, s. 14.
} 
dobnie zresztą jak rola rodzicielska, zajmują pozycję wyjątkową. Mamy oto do czynienia ze szczególną praktyką publicznego tolerowania szkodliwych i błędnych działań części nauczycieli, za które nie ponoszą oni żadnej odpowiedzialności tylko dlatego, iż nie powodują one „widocznych okaleczeń” i że pedagogom instytucjonalnym przypisana jest w tej sferze swoistego rodzaju moc nietykalności. Mimo iż ich toksyczne postępowanie może pozostawić głębokie, choć niewidoczne „rany” w strukturze psychicznej uczniów, to jednak odpowiedzialność sprawców ma charakter wyłącznie subiektywny (przed samym sobą), a więc żaden. Jeżeli nauczyciel będzie pozbawiony wrażliwości moralnej, to w zasadzie może to być równoznaczne z przyznaniem sobie przywileju bycia nieodpowiedzialnym. Szkoła staje się strefą niczyją, bezpańska, a jako taka musi żyć własnym życiem, przypadkowych zdarzeń, incydentów, wyrywanych przez każdą ze stron skrawków (pseudo-) wolności, szans na zaistnienie, spełnienie, realizację czegoś osobistego.

Są więc w niej nauczyciele pasjonaci, kochający swój zawód, czerpiący z niego sens własnego życia, ale są też i tacy, którym jest wszystko jedno. Przychodzą do niej, jak do „fabryki”, w której „pętający się” pod nogami uczniowie przeszkadzają im w ,pracy”. Są też uczniowie, którzy ulokowali w tej instytucji wszystkie swoje nadzieje, chcący zdobyć określoną wiedzę i kwalifikacje, a tym samym gwarancje na życiowy sukces. Są jednak i tacy, którzy już znacznie wcześniej zostali „poranieni” przez nauczycieli wcześniejszego etapu edukacji, zniechęceni do uczenia się, pozbawieni jakiejkolwiek wiary i ufności w sens zatroszczenia się poprzez edukację o siebie. Oni zostali już negatywnie naznaczeni, wykluczeni, a teraz - ponieważ muszą chodzić do szkoły - mogą jedynie znaleźć sobie zastępczą ofiarę, na której wyładują swoje dotychczasowe frustracje, bóle czy pozaszkolne nieszczęścia. No i wreszcie są też rodzice, korzystający z okazji, że ich dzieci, to już jednak nie dzieci, więc jakoś same dadzą sobie w szkole radę. Być może część spośród nich też nie lubi(-ła) szkoły, ma o niej złe mniemanie, więc niby czemu mieliby się angażować w jej pozytywny wymiar czy w naprawę?

Trzy światy trzech społeczności choć w sensie strukturalnym istnieją dla siebie, to jednak są obok siebie, a często i przeciwko sobie. Nie ma demokracji w otaczającym szkołę świecie, więc niby dlaczego miałaby mieć miejsce właśnie tu? Demokracja wiąże się z kontrolą nad środkami przemocy, a tego także obecne władze resortu edukacji wcale sobie nie życzą. Naprawa szkoły jest konieczna i możliwa zarazem. W przeciwnym wypadku szkoła publiczna zawsze będzie przedmiotem skrywanej i publicznej (najczęściej medialnej) krytyki. Szkoła unikająca zmiany zawsze będzie dramatem czy przestrzenią rodzącego się bólu egzystencjalnego uczniów, nauczycieli lub rodziców. Wydaje się, że taką przestrzenią, która pozwoli jej na powrót do tworzenia wspólnoty nauczycieli i uczących się powinna być powołana przez rodzi- 
ców, nauczycieli i uczniów rada szkoły. To w niej wszystkie strony uzyskują pełną (szczególnie w szkołach ponadgimnazjalnych) równowagę, pełną podmiotowość, pełną możliwość współdecydowania, współangażowania się w szeroko pojmowane procesy edukacyjne. To jest doskonałe miejsce, w którym można poznawać, odkrywać czy monitorować różne zdarzenia.

Można też rozliczać, kontrolować i oceniać siebie oraz innych, nie czekając na to, co ujawnią media. Wiadomo przecież, że w szkole jest dużo pozorów, ale i dużo rozwiązań, które są chybione, pozorne. Kto dzisiaj spośród uczniów i rodziców zna dobrze program wychowawczy szkoły, zna dobrze statut szkoły, zna wszystkie regulaminy, które i tak żyją własnym życiem? Zostawmy te regulaminy, statuty, programy. Budujmy program edukacyjny przez własną aktywność, własne działania, autentyczne zaangażowanie. Rady szkół są tym organem, w którym żadna ze stron nie uzyskuje nadwładzy. Każda społeczność może ją wykorzystać do rozwiązywania problemów w sposób godny i właściwy społecznie. To jest właśnie ta dobra przestrzeń, w której można zatrzymać proces wszelkiej niegodziwości czy toksyczności we wzajemnych relacjach ${ }^{31}$.

Szkoła tylko wówczas ma sens, kiedy staje się dla wszystkich jej podmiotów środowiskiem wzajemnego i autentycznego zainteresowania, troski oraz prawdziwego wysiłku. Tam, gdzie pozoruje się zaangażowanie w proces wychowania, przy nawet najlepszych regulaminach, statutach i systemach formalnego nagradzania nauczycieli i uczniów, nie można liczyć na rzeczywistą zmianę postaw. Ta bowiem wymaga szczerości, bezpośredniości, empatii i działania każdej z osób w zgodzie z obowiązującymi ją wartościami i normami. Media najczęściej interesują się dającymi się rozpoznać jako właśnie skrajne (bo rzadkie, nietypowe) takimi oddziaływaniami nauczycieli na uczniów, które choć może i są skuteczne, to jednak rodzą pytanie o ich sensowność. Niepotrzebnie, gdyż ich znaczenie wynika przecież z indywidualnego rozpoznania przez pedagogów swoistych uwarunkowań takich a nie innych zachowań uczniów, które wymagają określonej interwencji, jakiejś reakcji, zajęcia określonej wobec nich postawy.

Czyżby lepiej było udawać, że ich nie ma? Czy może działać tak, by nie będąc samemu posądzonym o brak reakcji, dać uczniom do zrozumienia, iż nasza tolerancja na zakres ich zachowań antyspołecznych czy szkodliwych dla ich osobistego rozwoju wynika z bezradności, a może nawet jakichś obaw i lęku? W edukacji nie ma standardowych rozwiązań dla trudnych sytuacji. Każdy pedagog musi je dobierać indywidualnie, stosownie do przyczyn zaistniałego zdarzenia, jego przebiegu i możliwych skutków. Musi w tym celu kierować się nie tylko osobistymi doświadczeniami i wiedzą (oby jak

${ }^{31}$ B. Śliwerski, Rada szkoły. Rada oświatowa, Kraków 2002. 
najgłębszą i wszechstronną) o uczniach w danym wieku życia oraz o wieku ich rozwoju psychospołecznego, ale także wyczuciem sytuacji, osobistym taktem i moralną wrażliwością. Ważną rolę odgrywa w tym wszystkim czas, którego najczęściej jest za mało, by można było spokojnie i z rozwagą przygotować się do adekwatnej interwencji.

Pedagog musi zatem łączyć w sobie rolę mistrza, przewodnika, artysty - wrażliwego na nieprzewidywalność końcowego efektu własnych działań - z rolą lekarza, terapeuty lub spolegliwego opiekuna interweniującego w ludzką biografię, w byt istoty często nieświadomej własnego potencjału i wynikających z jej zachowań zysków oraz strat rozwojowych. Pojawia się zatem pytanie, kiedy skończymy w szkołach z fikcją, działalnością pozorna, $\mathrm{z}$ ukrywaniem w niej pseudowychowania i udawaniem tego, czego w istocie w niej nie realizujemy, czyli zasad dialogu i demokratyzacji? Czyżby miało nadal obowiązywać ostrzeżenie Janusza Korczaka - „Rośnie nowe pokolenie, nowa wznosi się fala. Idą z wadami i zaletami; dajcie warunki, by wzrastali lepsi. Nie wygramy procesu z trumną chorej dziedziczności, nie powiemy chabrom, by były zbożem" "32.

Pedagog, który pracuje w szkole nie tylko dla materialnych korzyści, ale dlatego, że chce z głębszą refleksją odpowiedzialnie łączyć moc i wartość oddziaływań pedagogicznych z ich skutecznością dla dobra wspólnego, nie potrzebuje ministerialnego zobowiązania do swojego zaangażowania w proces kształcenia i wychowania, uczulania na jakieś wyjątkowe wartości czy idee dialogu. Powinien jedynie wczytać się w tkwiące w nim samym wartości, doznania, przeczucia i nadzieje, aby wpisywać je w szkolną codzienność. Edukuje bowiem sobą i poprzez siebie. Jak pisze w jednym ze swoich wierszy poetka Irena Conti di Mauro -

Każdy człowiek może stać się

Wspaniałym cudotwórcą

Kiedy nie czeka na ten wielki cud

Tylko z małych cudów

Które zdarzają się codziennie

Potrafi uzbierać ten wielki $[\ldots]^{33}$.

\section{Is dialogue possible in school? (Summary)}

The author of the paper analyses a school reality, posing a question, if it benefits a student by giving some space for autonomy or it deters it by realising the aims

${ }^{32}$ J. Korczak, dz. cyt., s. 87.

${ }^{33}$ I. Conti di Mauro, Lubię codzienność, Warszawa 2005, s. 14. 
of educational authorities, limiting his freedom and subjectivity. Undertaking the analysis, the author notices that the autonomy in the school is influenced by wider processes, including educational policy. According to him, the postulates which were discussed in the 1980s, aiming at democratisation of the school, have not been realised. A strong subordination of the schools to the educational authorities results in authoritarian relations in the school itself, comprising the heads and teachers, the school board and parents as well as the relations between teachers and students. Exemplifying the author underlines that the democratic structures only pretend the existence of autonomy in the school. He claims that the space allowing for a return to the creation of a community of the teachers and students should be the board of school comprising of both parents, teachers, and students. Here, all the structures find certain balance, especially in the secondary schools, full subjectivity, the decision-making capability, sharing the power of mutual engagement in the broadly understood educational processes. 